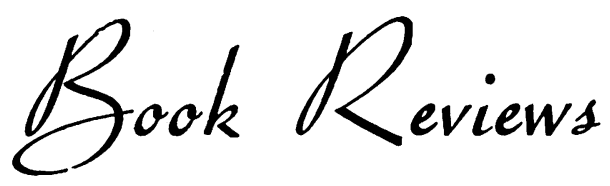

\section{THE MEDICAL ANNUAL 1956}

Edited by Sir Henry TIDy, K.B.E., M.A., M.D., F.R.C.P., and R. Milnes Walker, M.S., F.R.C.S. Pp. $x 1+548$, illustrated. Bristol: John Wright \& Sons Ltd. 1956. 38s. 6d.

The Medical Annual has a secure reputation as a source of thoughtful, critical reviews of recent medical advances, and the present edition is worthy of its predecessors.

The articles take the form of short reviews of progress in fairly limited fields, and the papers quoted are often abstracted in considerable detail. Thus, though there is no attempt to cover all the developments in every field, yet those selected for review receive thorough and critical treatment.

To single out any particular article for commendation would be invidious since the standard is high throughout. General practitioners as well as specialists in isolated fields will find this book interesting and profitable.

\section{THE LIFE OF HUGH OWEN ITHOMAS}

By David Le Vay, M.S., F.R.C.S. Pp. viil+ 135 , illustrated. Edinburgh: E. \& S. Livingstone Ltd. 1956. 25 s.

There must be many for whom the name of Hugh Owen Thomas means little but the name of a splint, a physical sign, and a misty figure of controversy at the end of the last century. This book establishes Thomas as one of the surgical immortals. The complexity of character of this strange figure is revealed in his portrait by Fleury which is reproduced on the cover. The factors underlying this character are well described in this biography, from which there emerges a picture of a man with many personal idiosyncracies but endowed with an honesty of purpose, a clear scientific outlook and an unremitting attention to the details of surgical methods which caused him to be acknowledged as a genius by his patients and by many surgeons of international reputation, although he was ignored by most of his surgical contemporaries in this country. Apart from his great contribution to orthopaedic surgery, it is interesting to find that Thomas held very modern views on some aspects of abdominal surgery such as the correct principles for the treatment of ileus and the conservative treatment of appendicitis.

This book is strongly recommended, being well written and of absorbing interest.

\section{INJURIES OF THE HAND}

By Ronald Furlong, F.R.C.S. Pp. vii +215 , with 99 illustrations. London: J. \& A. Churchill Ltd. $1957.36 \mathrm{~s}$.

Mr. Furlong has written an excellent short book on injuries of the hand which is sure of a welcome from all surgeons and from Casualty Officers and postgraduate students in particular. Writing in a very easy and occasionally provocative style he covers the whole field of hand surgery as it is seen in the Casualty Department. The first two chapters deal with the important aspects of the anatomy of the hand and in general terms with technique. In the subsequent chapters are considered injuries of the skin, tendons and nerves, and infections of the hand and fingers. The last chapter deals with common post traumatic disabilities. As would be expected, Mr. Furlong has devoted a good deal of space to the consideration of tendon injuries, but most readers will be glad to learn from his special experience in this tield and will not find this chapter too long. He has wisely not attempted to deal, except in the most general terms, with the subject of the late reconstruction of the injured hand.

Not all of Mr. Furlong's colleagues will agree with all of his views as expressed in this book, but all will agree that these views are based on a wide experience, that his recommendations are founded on logical reasoning and that throughout the book allowance is made for other modes of thought. It is perhaps a small defect of the book that no references are given, as some guide to further reading would have been a help to the postgraduate student.

The illustrations are well chosen and the standard of production is excellent. The book should do much to raise the standard of hand surgery in this country and it is to be hoped that it will be read by all those concerned with the primary treatment of these very important injuries.

\section{SYMPOSIUM OF TUBERCULOSIS}

Edited by F. R. G. Heaf, M.A., M.D., F.R.C.P. Pp. xvi +755 , with 78 illustrations. London: Cassell \& Company Ltd. 1957. £5 5s.

This is a very full account of all the manifestations of tuberculosis in man. Being a symposium, it has the advantage of a selected expert to deal with 